\title{
Archivos Argentinos de Pediatría turns 85 years old
}

This month is our journal's anniversary: 85 years have elapsed since its first publication in April 1930. Therefore, this a good time to reminisce some of the most remarkable aspects since its start, pay homage to its creators and to those who have made great efforts over these years to make Archivos Argentinos de Pediatria become what it is today.

Our first editorial started with "In fact, this journal is not a new organ of medical journalism, it is simply a vigorous shoot from the old trunk called Archivos Latino Americanos de Pediatría, which, for many years, contained most of the Argentine and Uruguayan pediatric bibliography." This message, unique because of its honesty and modesty, clearly underscores the origin of our journal, and also states that it will follow the path of the organ that preceded it. Likewise, another paragraph honors those who conceived Archivos Latino Americanos de Pediatria, with this wording: "This homage would be ungrateful if we did not mention Gregorio Aráoz Alfaro, M.D., and Luis Morquio, M.D., founders and directors...." Olinto de Oliveira, M.D., from Porto Alegre and Fernandes Figueiras, M.D., from Rio de Janeiro (Brasil) also took part at the dawn of this journal.

After 25 years, societies of pediatrics decided it was about time for each one to have its own journal and this led to the birth of our journal in Argentina as well as in Uruguay, Brazil and Chile.

In those days, the Sociedad Argentina de Pediatría was presided over by Professor Alfredo Casaubón, a leader in pediatrics nationwide and Head of the Department of Hospital de Niños de Buenos Aires; its vice president was Juan P. Garrahan, M.D. Our first director was María Teresa Vallino, M.D., from Hospital de Clínicas de Buenos Aires, a curiosity in those times when women's presence in medicine was still scarce. She continued as director of Archivos Argentinos de Pediatría for the first seven years, and her work was truly praiseworthy and laid the foundations of our journal. The subsequent directors were amongst the most revered figures in Argentine pediatrics. It is worth noting some of those who had a great commitment and special devotion to our journal. María Teresa Vallino, M.D., was succeeded by Juan P. Garrahan, M.D., in 1937, who served as director for 10 years, a decade that brought much prestige to the our Journal. He was followed by Florencio Escardó, M.D., who contributed his wealth of cultural background and gift for writing to make our journal stand out. He was succeeded by Alfredo Larguía, M.D., (19491953) who was the director again between 1961 and 1965. In the eight years he was in charge, he maintained a great level of commitment, and his talent as a remarkable teacher and excellent human being provided the journal with a wider vision, adapting to the changes that were taking place in the publications from other countries.

In the following years, outstanding pediatricians directed the Archivos Argentinos de Pediatría, including Juan Murtagh, M.D., (19651969) who became a tireless collaborator of the Sociedad Argentina de Pediatría (he facilitated the purchase of the house on Coronel Díaz street, which finally enabled us to have our own office more than 50 years after its foundation). Teodoro Puga, M.D., was also of great assistance in every position he held. He was director between 1975 and 1979, and in this period he finally regained the Society's intellectual property. He was succeeded by Abel Bettinsoli, M.D., (1979-1981) who put all his effort and dedication to maintain the line of work of his predecessors.

In 1984, Carlos Gianantonio, M.D., took over the presidency of the Sociedad Argentina de Pediatria and asked me to be the editor of our journal, the Archivos Argentinos de Pediatría, which was then going through a dark period and whose quality had decreased in the context of a country where democracy was yet to return. I was greatly honoured that Dr. Gianantonio, our dear and always-present teacher, had entrusted me this task. With his support and that of the Steering Committee, as well as that of Gerda Rhades, marvelous and tireless collaborator, relentless improvements where made throughout his six years of management. Peer review was implemented for the first time, publications started being regularly published, and towards the end of the cycle, the first attempt was made to have the journal indexed in Medline. Between 1990 and 1997, Ramón Exeni, M.D., was in charge. During his administration, a formal request was submitted to the National Library of Medicine, and though it was not possible to be part of Medline, it set the basis for considering the steps to follow. In 1997, the Publication Council was created. Its director up to 2006, Teodoro Puga, M.D., made significant advancements in the journal and also in multiple publications. During this period, Archivos Argentinos de Pediatría was directed by Horacio Repetto, M.D., (1997-2000) and Carlos Wahren, M.D., (2000-2006), with the assistance of Carmen De Cunto, M.D. They continued laying the most state-of-the-art foundations to further enhance the journal's prestige. In March 2006, at the 
request of Mario Grenoville, M.D., then president of the Sociedad Argentina de Pediatría, I resumed as editor and author of the Archivos Argentinos de Pediatría two decades after my first experience. At the beginning, I had the excellent collaboration of Hebe González Pena, M.D., as Assistant Editor, although she was with us for less than one year, since her obligations and responsibilities as Head of Service were not compatible with the requirements of this task. She was replaced by Norma Rossato, M.D., who continues in her position and has been an exceptional collaborator and a true pillar along the entire editorial process. Together, we have established an excellent group of assistant editors, all committed to their positions, who really contribute to keep up the difficult task required by the journal.

I would like to highlight two major accomplishments: having been accepted by Medline in 2008, which was a fundamental historical landmark, and the progressive translation of articles into English since 2012.
These two landmarks have allowed Archivos Argentinos de Pediatría to gain significance worldwide, its presence has advanced slowly but markedly, and at present it occupies a prominent place among pediatric journals edited in Spanish.

At present, the president of the Sociedad Argentina de Pediatría is Ángela Gentile, M.D., who together with the Steering Committee provide us with strong support, enabling us to face challenges, maintain our achievements and make improvements to attain new goals.

Thereby, we will be fulfilling the wishes of the pioneers who created this journal 85 years ago as the official organ of the Sociedad Argentina de Pediatría, and who today we are paying emotional homage to all those pediatricians who have shaped the present of the Archivos Argentinos de Pediatría.

José M. Ceriani Cernadas Editor

http:/ /dx.doi.org/10.5546/aap.2015.eng.98

\section{Archivos 85 years ago}

\section{Aก̃o 1 \\ Abril de 1930 \\ archivos argentinos de PEditría PUBนAesctóx MEXstus.}

N. 1

(Organo Oficial de La Sociedad Argentina de Pediatría)

\section{Archivos Argentínos de Pediatría}

Esta revista no es, en realidad, un nuevo órgano del periodismo médico; es sólo un retoño vigoraso del viejo tronco que se llamó "Archivos Latino-Americanos de Pediatria" y que durante varios lustros registró en sus páginas la mayor parte de la bibliografía especializada argentino - uruguaya.

Pero aquella publicación, común a las Sociedades de Pediatría de ambos países, cumplió ya-y por cierto que brillantementela misiín para la que habia sido creada y hoy cada una de las referidas entidades edita ya su revista propia $e$ independiente. El ritmo de la vida exige imperiosamente la renotación de los hombres $y$ las cosas...

Mientras tanto, rindamas el homenaje de nuestra consideración y respeto al viejo portavoz desaparecido, que vió los albores de la Pediatría argentina, asistió a su vigoroso desenvolvimiento y alcanzó su fecunda madurez actual.

Seria una ingratitud no asociar especialmente a ese homenaje los nombres de los Dres. Gregorio Aráoz Alfaro y Luis Morquio, que fundaron y dirigieron los "Archivos", impulsándolos en la senda del progreso con sus indiscutitles prestivios cientificos, sue soste-

"Archivos Argentinos de Pediatría", órgano oficial de la "Socicdad Argentina de Pediatría", aparecerá mensualmente y sus columnas quedan abiertas a todos los estudiosos, para la publicación de trabajos exclusivamente cientificos y sin otras limitaciones que las impuestas por la especialidad en sus diversas disciplinas y la seriedad y ética de una revista que nace siendo tribuna alta y genuina de la Pediatria de nuestro país.

\section{ARCHIVOS ARGENTINOS DE PEDIATRIA}

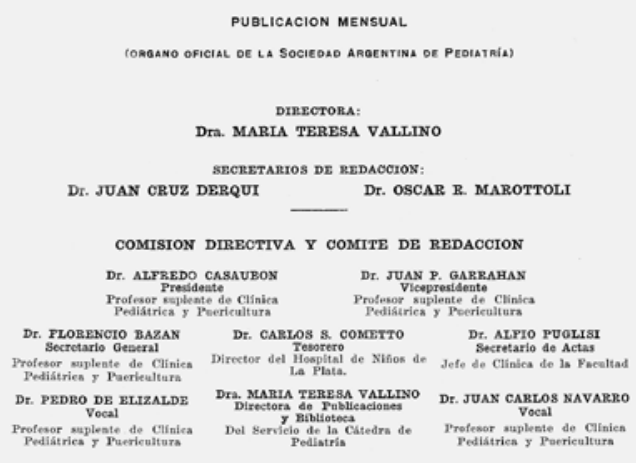




\section{Scientific publication: How to handle rejection?}

Every year, millions of manuscripts are submitted to thousands of scientific journals looking for publication. It is estimated that more than one million new scientific articles are published every year by the most important scientific journals, and a significant number of these are related to medicine. ${ }^{1}$ Considering that journal acceptance rates are scarcely above 30\% -and may be less than $5 \%$ for some $-^{2}$ rejection letters are sent to millions of authors every year. The way we, as authors, handle rejection, can probably make a difference.

In their excellent article, Venketasubramanian and Hennerici ${ }^{3}$ suggest that on receipt of notification of rejection one may initially experience a paralyzing shock, followed by the five stages of the Kübler-Ross grief cycle (denial, anger, bargaining, depression and acceptance). I believe that anger usually takes over the scenario (at least according to my own experience). Once this initial anger is overcome, it is necessary to analyze the notification of rejection.

If the manuscript was rejected due to administrative reasons, it means we failed to comply with the instructions for authors. It is our own fault, without exception.

If the manuscript was rejected by the journal editors (with no feedback from reviewers), either our manuscript was really poor (it stinks!) or, most likely, we sent it to the wrong journal. Although editors are not infallible, they have the obligation to go through the hundreds of articles they receive to select only those they believe will be the most interesting to their readers. Many good articles are rejected by certain journals but gladly welcomed by others. It is essential for us to assess which publication will take interest in our work.

Lastly, if the manuscript was rejected following a peer review, we should take other factors into consideration. In general, our first impression is that peer reviewers did not understand our work. This is the case many times, but we should also bear in mind that the fact that they did not understand is exclusively our fault. Our obligation is to write an article that can be understood by the general public, not just by our team, who has spent their last 15 years focused on this specific matter. In addition, even with limitations, editors usually select reviewers among renowned professionals in each subject matter. Secondly, we usually feel like there is a conspiracy against us and that peer reviewers only want to harm us for the strangest reasons. We should bear in mind that editorial work is a burden on those who do it and they are usually driven by altruistic reasons. It is true that the peer review process is continuously discussed, ${ }^{4}$ but almost everyone agrees that, so far, it is the best option we have.

Once we contemplate that peer reviewers are not illiterate or hate us, we can then go over every item in their criticism and suggestions to correct our manuscript, either accepting their recommendations or backing up the elements that were not adequately stated in our first version.

If following rejection, we are allowed to send a new version, we will reply to each and every comment made by reviewers. If rejection is irreversible, we will submit our work to another journal, knowing that our article is now improved thanks to the work of editors and peer reviewers. It is not unusual that after three rejections, our article is accepted as is, with no amendments, and in record time by the fourth journal we had submitted it to. Our arrogance probably makes us believe that we have at last found a respectable group of scientists who appreciate our efforts and forget that our manuscript has been significantly improved by three previous reviews.

Fernando Ferrero, M.D.

Hospital General de Niños Pedro de Elizalde

http:/ /dx.doi.org/10.5546/aap.2015.eng.100

1. Björk B-C, Roos A, Lauri M. Scientific journal publishing: yearly volume and open access availability. Information Research 2009;14(1):paper 391. [Accessed on: November 4, 2014]. Available at: http://InformationR.net/ir/14-1/ paper391.html

2. The Lancet. How The Lancethandles your paper. [Accessed on: November 4, 2014]. Available at: http:/ / www.thelancet. com/lancet-information-for-authors/how-the-lancethandles-your-paper

3. Venketasubramanian N, Hennerici MG. How to handle a rejection. Teaching course presentation at the 21st European Stroke Conference, Lisboa, May 2012. Cerebrovasc Dis 2013;35(3):209-12.

4. Berquist TH. Peer review: should we modify our process? AJR Am J Roentgenol 2014;202(3):463-4. 